\title{
Barotropic background currents in the Gulf of California
}

\section{Corrientes básicas barotrópicas en el Golfo de California}

\author{
Vyacheslav Makarov* \\ Ángel Jiménez-Illescas \\ Centro Interdisciplinario de Ciencias Marinas \\ Instituto Politécnico Nacional de México \\ Av. Instituto Politécnico Nacional s/n \\ Col. Palo de Santa Rita \\ Apartado postal 592 \\ La Paz, CP 23096, Baja California Sur, México \\ *E-mail: smakarov@ipn.mx
}

Recibido en junio de 2002; aceptado en diciembre de 2002

\begin{abstract}
A field of barotropic background currents (BC) in the Gulf of California is constructed numerically. The definition of BC used here is based on suppositions about (i) the horizontal homogenization of potential vorticity in large-scale gyres, and (ii) the tendency of a current structure to evolve to a state with a minimum of system mechanical energy. In the barotropic case here, the numerical algorithm is reduced to the solution of the Dirichlet boundary problems for planetary, topographic and flowing integral streamfunction components separately. The results obtained are compared to observations and the results of other numerical models. The calculated barotropic BC realistically describe the main features of the circulation in the southern part of the Gulf of California, including its mouth. Cyclonic movement in the deep-water and anticyclonic movement near the coasts are observed. The numerical results for the central and northern parts of the gulf, where seasonal climatological differences are pronounced, coincide with observations in the upper layer only during the winter season; i.e., the circulation here is anticyclonic. Thus, there are reasons to suggest that mainly planetary-topographic forcing, especially in the southern part, forms the circulation in the lower layer. The seasonal variability of currents in the upper layer caused by non-stationary effects such as wind, heat flux and baroclinicity, is apparently in phase with these mechanisms during winter, and in antiphase during summer, particularly for the central and northern gulf.
\end{abstract}

Key words: Gulf of California, background currents, potential vorticity, barotropic model, planetary-topographic forcing.

\section{Resumen}

Un campo de corrientes básicas (CB) barotrópicas en el Golfo de California se construyó numéricamente. La definición de $\mathrm{CB}$ utilizada aquí se basa en las suposiciones sobre (i) la homogeneización horizontal de vorticidad potencial en los giros de macroescala y (ii) la tendencia de la estructura de las corrientes a evolucionar hacia un estado con un mínimo de energía mecánica del sistema. En un caso barotrópico el algoritmo numérico se reduce a la solución, separadamente, de los problemas de frontera de Dirichlet para las componentes topográfica, planetaria y de flujo de la función integral de corriente. Los resultados obtenidos se compararon con las observaciones y con los resultados de otros modelos numéricos. Las CB barotrópicas calculadas describen, de una manera realista, las características principales de la circulación en la parte sur del Golfo de California, incluyendo su boca. Se ha observado aquí un movimiento ciclónico en agua profunda y un movimiento anticiclónico cerca de ambas costas. Los resultados numéricos para las partes central y norte del golfo, donde las diferencias climatológicas estacionales son pronunciadas, coinciden con las observaciones en la capa superior solamente durante la estación de invierno; i.e., la circulación aquí es anticiclónica. Por tanto, hay razones para sugerir que principalmente el forzamiento topográfico-planetario, especialmente en la parte sur, forma la circulación en la capa inferior. La variabilidad estacional de las corrientes en la capa superior, causada por efectos no estacionarios tales como el viento, el flujo de calor y la baroclinicidad, aparentemente está en fase con estos mecanismos durante el invierno y está en antifase durante el verano, particularmente para la parte central y norte del golfo.

Palabras clave: Golfo de California, corrientes básicas, vorticidad potencial, modelo barotrópico, forzamiento planetariotopográfico. 


\section{Introduction}

The hydrographic investigations in the Gulf of California have more than one century of history. Descriptions of the area and the results of oceanographic surveys in the gulf can be found, for example, in the review papers of Roden (1958, 1964), Álvarez-Borrego (1983), Cano-Pérez (1991), and Bray and Robles (1991). Later reviews (Lavín et al., 1997a; Marinone and Lavín, 1997) also include the outcomes of numerical modeling.

This semi-enclosed sea is a large evaporation basin that has its own warm, highly saline water mass of several types (Bray, 1988b), but there is no record of any permanently existing current here. Pronounced seasonal variability of many oceanographic parameters is a characteristic feature of the dynamic and thermohaline structure in the gulf (Baumgartner and Christensen, 1985; Robles and Marinone, 1987; Ripa, 1997). An exception is a vorticity field, which does not show a seasonal cycle, at least in the central gulf (Ripa and Marinone, 1989). Another generally accepted fact is the monsoon-type wind: stronger down-gulf (i.e., northwesterly) during most of the year and weaker up-gulf (southeasterly) in the subtropical summer (Badan-Dangon et al., 1991). Other causes of seasonal variability in the upper layer are different thermohaline structure-forming conditions (e.g., Bray, 1988b) and the influence of the Pacific Ocean through the mouth, for example in the form of a Kelvin wave (Beier, 1997; Ripa, 1997).

The entrance to the gulf is wide and very deep, and thus has its own complicated dynamics, which until now has not been fully studied. Water transport estimates vary from $0.9 \mathrm{~Sv}$ (Bray, 1988a, for the central part) to $12 \mathrm{~Sv}$ (Roden, 1972). Furthermore, there is no unified opinion regarding the circulation direction. It is traditionally considered that in summer, outflow of gulf water occurs along the coast of the Baja California peninsula and ocean water penetrates along the coast of the mainland, and that in winter, the situation is reversed (e.g., Bray, 1988a; Beier, 1997). Castro et al. (2000) reported that the water exchange at the mouth occurs via cyclonic circulation in spring, fall and winter.

The intricate bottom relief complicates the dynamics even further. The bathymetry of the Gulf of California consists of a system of semi-local basins arranged lengthwise along the gulf that deepen approaching the entrance. The northern gulf is rather shallow, while the continental shelf in the center and south has only a narrow zone, predominantly near the mainland coast. Such a structure should promote the generation of differently scaled eddies and dynamical fronts, which are evident in satellite infrared imagery (Badan-Dangon et al., 1985; Paden et al., 1991; Santamaría-del-Ángel and ÁlvarezBorrego, 1994; Lavín et al., 1997b). These effects were also detected by means of the analysis of geostrophic currents from temperature and salinity observations (Álvarez-Sánchez et al., 1978; Marinone and Ripa, 1988; Fernández-Barajas et al., 1994; Collins et al., 1997), and identified on the basis of direct

\section{Introducción}

Las investigaciones hidrográficas en el Golfo de California tienen más de un siglo de historia. La descripción del área y los resultados de las observaciones oceanográficas en el golfo se pueden encontrar, por ejemplo, en artículos de revisión de Roden (1958, 1964), Álvarez-Borrego (1983), Cano-Pérez (1991) y Bray y Robles (1991). Los últimos artículos de revisión (Lavín et al., 1997; Marinone y Lavín, 1997) también incluyen resultados de modelación numérica.

Este mar semicerrado es una gran cuenca de evaporación y tiene su propia masa de agua caliente y de alta salinidad, con varios tipos (Bray, 1988b), pero no se ha registrado aquí ninguna corriente permanente. La pronunciada variabilidad estacional de muchos parámetros oceanográficos es una peculiar característica de la dinámica y de la estructura termohalina en el golfo (Baumgartner y Christensen, 1985; Robles y Marinone 1987; Ripa, 1997). La excepción es un campo de vorticidad, el cual no muestra un ciclo estacional, al menos en la parte central del Golfo de California (Ripa y Marinone, 1989). Otro hecho generalmente aceptado es el viento tipo monsón: más fuerte hacia la boca del golfo (i.e., del noroeste) durante la mayor parte del año y más débil hacia dentro del golfo (i.e., del sureste) en el verano subtropical (Badan-Dangon et al., 1991). Las otras causas de variabilidad estacional en la capa superior son las diferentes condiciones de la formación de la estructura termohalina (e.g., Bray, 1988a) y la influencia del Océano Pacífico a través de la boca, por ejemplo en la forma de una onda de Kelvin (Beier, 1997; Ripa, 1997).

La entrada del golfo es ancha y muy profunda y por eso tiene su propia dinámica complicada, la cual hasta ahora no ha sido completamente estudiada. Las estimaciones del transporte de agua varían entre 0.9 Sv (Bray, 1988a, para la parte central) y $12 \mathrm{~Sv}$ (Roden, 1972). Adicionalmente, no hay una opinión unificada con respecto a la dirección de la circulación. Tradicionalmente se considera que en verano, el flujo hacia fuera del golfo ocurre a lo largo de la costa de la península de Baja California y las aguas oceánicas penetran a lo largo de la costa continental, mientras que en invierno la situación es inversa (e.g., Bray, 1988b; Beier, 1997). Castro et al. (2000) reportaron que el intercambio de agua en la boca ocurre vía circulación ciclónica en primavera, otoño e invierno.

El intrincado relieve del fondo complica la dinámica aún más. La batimetría del Golfo de California consiste en un sistema de cuencas semilocales arregladas a lo largo del golfo que se hacen más profundas al aproximarse hacia la boca. La parte norte es bastante somera, mientras que la plataforma continental en el centro y sur del golfo mantiene una zona angosta, predominantemente cerca de la costa continental. Tal estructura debe promover la generación de remolinos de diferentes escalas y frentes dinámicos, los cuales son evidentes en las imágenes de satélite (Badan-Dangon et al., 1985; Paden et al., 1991; Santamaría-del-Ángel y Álvarez-Borrego, 1994; Lavín et al., 1997b). Estos efectos también fueron detectados mediante el 
current measurements (Collins et al., 1997; Emilsson and Alatorre, 1997; Lavín et al., 1997b). In addition, the gulf's gaunt configuration causes strong tidal effects, especially in the north, with amplitudes of more than $10 \mathrm{~m}$ and velocities of 2-3 $\mathrm{m} \mathrm{s}^{-1}$. Such complicated interactions of dynamic phenomena hamper detection of the relative roles of mechanisms and the definition of the hierarchy of these processes on the basis of only oceanographic observations. For this, it is necessary to use numerical simulation.

Various models have been used for the numerical simulation of circulation in the Gulf of California. Dressler (1981) modeled wind-driven vertically integrated currents; Carbajal (1993) applied a three-dimensional homogeneous model. A two-layer linear baroclinic model was used by Beier (1997) for the study of a seasonal cycle in the gulf. Mesoscale circulation induced by atmospheric effects was studied by Martínez (2002). The numerical simulation of the main (somehow background) circulation in the Gulf of California is carried out, as a rule, with the aid of different models of tide- and/or wind-induced residual currents (e.g., Argote et al., 1998). The influences of the most important tidal constituents (Marinone, 1997) and the topographic stress parameterization effects (Marinone, 1998) on circulation were studied. An interesting approach was used by Velasco-Fuentes and Marinone (1999), who investigated advective transport in the field of the flows, computed by a non-linear two-dimensional barotropic model with tide and wind. Most numerical models reproduce the following surface circulation characteristics: generally cyclonic in summer and anticyclonic in winter, with an expressed gyre in the northern part of the gulf and alongshore flows in the southern part. Due to insufficient hydrographic observations for the entire gulf, the baroclinic factors were taken into account on the assumption of a two-layer ocean only (Beier, 1997).

In this study, we attempt to simulate background or main currents forced by only basic stationary mechanisms, reflecting the properties of the region without the influence of external non-steady factors such as wind stress, heat flux and tides. The results of calculations for the Gulf of California with a simple but sufficiently meaningful barotropic model are presented. The results obtained were compared with the existing concepts about the peculiarities of the circulation in this region.

\section{Methodology}

The notion of background currents, usually defined as a circulation averaged in some way, is widely used in dynamic oceanology. Here, we used a constructive definition of this notion that was offered by Kozlov (1995). This approach is based on the assumption of conservation of potential vorticity (hereafter PV) $\Pi$, which is one of the basic characteristics of quasi two-dimensional geophysical currents. It combines contributions of relative vorticity, planetary-topographic interactions and stratification in a general case. The PV in the case análisis de las corrientes geostróficas, calculadas a partir de observaciones de temperatura y salinidad (Álvarez-Sánchez et al., 1978; Marinone y Ripa, 1989; Fernández-Barajas et al., 1994; Collins et al., 1997), y se identificaron con base en mediciones directas de corrientes (Collins et al., 1997; Emilsson y Alatorre, 1997; Lavín et al., 1997b). Además, la alargada configuración del golfo causa fuertes efectos de marea, especialmente en el norte, con amplitudes de más de $10 \mathrm{~m}$ y con velocidades de 2 a $3 \mathrm{~m} \mathrm{~s}^{-1}$. Tales interacciones complicadas de los fenómenos dinámicos obstaculizan la detección del papel relativo que juega cada uno de los mecanismos y la definición de la jerarquía de estos procesos solamente con base en observaciones oceanográficas. Para hacer esto, es necesario usar simulación numérica.

Varios modelos han sido utilizados para la simulación numérica de la circulación del Golfo de California. Dressler (1981) modeló las corrientes impulsadas por el viento, verticalmente integradas; Carbajal (1993) aplicó un modelo homogéneo tridimensional. Un modelo baroclínico lineal de dos capas fue usado por Beier (1997) para el estudio de un ciclo estacional en el golfo. La circulación de mesoescala debida al forzamiento atmosférico fue estudiada por Martínez (2002). La simulación numérica de la circulación principal (i.e., de alguna manera la circulación básica) en el Golfo de California generalmente se lleva a cabo utilizando diferentes modelos de corrientes residuales, inducidas por la marea y/o por el viento (e.g., Argote et al., 1988). Se estudiaron las influencias sobre la circulación de las constituyentes más importantes de la marea (Marinone, 1997) y de los efectos de la parametrización del esfuerzo topográfico (Marinone, 1998). Un interesante enfoque fue usado por Velasco-Fuentes y Marinone (1999), quienes investigaron un transporte advectivo en el campo de velocidades, calculadas por un modelo barotrópico bidimensional no lineal con marea y viento. La mayoría de los modelos numéricos reproducen las siguientes características de circulación superficial: generalmente ciclónico en verano y anticiclónico en invierno, con un giro explícito en la parte norte del golfo y con flujos a lo largo de ambas costas en la parte sur. Debido a una insuficiente observación hidrográfica para el golfo entero, los factores baroclínicos fueron tomados en cuenta solamente bajo la suposición de un océano de dos capas (e.g., Beier, 1977).

En este estudio se intenta simular las corrientes básicas o corrientes principales, forzadas solamente por mecanismos básicos estacionarios, los cuales reflejan las características propias de la región, sin la influencia de los factores externos no estacionarios, tales como el esfuerzo del viento, el flujo de calor y las mareas. Se presentan los resultados de los cálculos para el Golfo de California mediante un modelo barotrópico simple, pero suficientemente significativo. Los resultados obtenidos fueron comparados con los conceptos existentes sobre las peculiaridades de la circulación en esta región. 
of infinitesimally small viscosity is a Lagrangian invariant, i.e., it satisfies the equation (Pedlosky, 1979):

$$
d \Pi / d t \equiv \Pi_{t}+u \Pi_{x}+v \Pi_{y}=0
$$

where $(u, v)$ is the vector of horizontal velocity. Due to its invariance, the field of $\mathrm{PV}$ is a more suitable characteristic for the determination of the current structure than relative vorticity, so the currents with horizontally homogeneous distribution of PV satisfying (1) can be reasonably accepted as background currents (hereafter BC). The so-called Rhines-Young theorem (Rhines and Young, 1982), often applied both for the construction of different models and for the interpretation of observations, can be used to substantiate the homogenization of PV. It is clear that the structure of the currents depends on the magnitude of PV. The unique solution may be selected on the criterion that the total mechanical energy (sum of kinetic and sensible potential energies) of the system should be minimal. This allows finding a unique value of PV and calculating the relative vorticity field corresponding to it. In general, the background relative vorticity is a function of bottom relief, planetary vorticity and stratification. Some results of the modeling and analysis of $\mathrm{BC}$ for the Japan and Okhotsk seas were obtained by Kozlov and Makarov (1996a, b) using this approach.

\section{The model}

As is known (see Von Schwind, 1980) for a barotropic ocean, PV has the form

$$
\Pi=(\omega+f) / H
$$

where $f(x, y)$ is the Coriolis parameter associated with planetary vorticity, $\omega=v_{x}-u_{y}$ is the relative vorticity, and $H(x, y)$ is the depth of the sea. Under the condition of a "rigid lid" at the surface, $\omega$ is defined by means of the integral streamfunction $\Psi$ using the well-known relation

$$
\omega=L \Psi \equiv\left(\Psi_{x} / H\right)_{x}+\left(\Psi_{y} / H\right)_{y}
$$

Substitution of (3) into (2) leads to the subsequent equation for the integral streamfunction

$$
L \Psi=\Pi \cdot H-f
$$

For the nearly closed area $D$, the boundary condition can be written as

$$
\left.\Psi\right|_{\partial D}=\Psi^{(b)}(l, t)
$$

where $l$ is the coordinate along $\partial D$ and $\Psi^{(b)}$ is the given water transport, for example, through the straits. For constant

\section{Metodología}

La noción de corrientes básicas, usualmente definidas como una circulación promediada de alguna manera, es ampliamente usada en la oceanología dinámica. Aquí se usa una definición constructiva de esta noción que fue ofrecida por Kozlov (1995). Este enfoque se basa en la suposición de conservación de la vorticidad potencial (de aquí en adelante VP) П, la cual es una de las características básicas de las corrientes geofísicas cuasibidimensionales. La VP combina contribuciones de vorticidad relativa, interacciones planetariastopográficas y estratificación en un caso general. En el caso de viscosidad infinitesimalmente pequeña, la $\mathrm{VP}$ es una invariante lagrangeana, i.e., satisface la ecuación (Pedlosky, 1979):

$$
d \Pi / d t \equiv \Pi_{t}+u \Pi_{x}+v \Pi_{y}=0
$$

donde $(u, v)$ es el vector de velocidad horizontal. Debido a su invariancia, el campo de VP es una característica más apropiada para la determinación de la estructura de la corriente que la vorticidad relativa, por eso las corrientes con distribución horizontalmente homogénea de VP, que satisface (1), pueden ser razonablemente aceptadas como corrientes básicas (de aquí en adelante CB). Para la sustentación de la homogeneización de la VP se puede usar el llamado teorema de Rhines-Young (Rhines y Young, 1982), que frecuentemente se aplica para la construcción de los distintos modelos y en la interpretación de las observaciones. Es claro que la estructura de las corrientes depende de la magnitud de VP. La solución única puede ser seleccionada con el criterio de que la energía mecánica total (suma de energías cinética y potencial sensible) del sistema debería ser la mínima. Esto permite encontrar un valor único de VP y calcular el campo de vorticidad relativa correspondiente a él. En general, la vorticidad relativa básica es una función del relieve del fondo, de la vorticidad planetaria y de la estratificación. Algunos resultados de la modelación y análisis de CB para los mares de Japón y Okhotsk fueron obtenidos por Kozlov y Makarov (1996a, b) usando este método.

\section{El modelo}

Como se sabe (ver Von Schwind, 1980), para un océano barotrópico la VP tiene la forma

$$
\Pi=(\omega+f) / H
$$

donde $f(x, y)$ es el parámetro de Coriolis asociado con la vorticidad planetaria, $\omega=v_{x}-u_{y}$ es la vorticidad relativa y $H(x, y)$ es la profundidad del mar. Bajo la condición de "tapa rígida" en la superficie, $\omega$ se define por medio de la función integral de corriente $\Psi$ usando la bien conocida relación

$$
\omega=L \Psi \equiv\left(\Psi_{x} / H\right)_{x}+\left(\Psi_{y} / H\right)_{y}
$$


$\mathrm{PV}$, the conservation law is identically valid, and the derivative $\Phi=\partial \Psi / \partial \Pi$ according to (1) and (2) is the solution of the boundary problem

$$
L \Phi=H,\left.\Phi\right|_{\partial D}=0
$$

The kinetic energy $E=(1 / 2) \cdot \int_{D}(1 / \mathrm{H}) \cdot(\nabla \Psi)^{2} d D$ is a square function of the parameter $\Pi$, where $\nabla$ is a two-dimensional nabla operator. The derivation by this parameter leads to the expression

$$
\begin{aligned}
\partial E / \partial \Pi & =\int_{D} H^{-1} \cdot \nabla \Psi \cdot \nabla \Phi d D \\
& =\int_{D}[\nabla(\nabla \Psi \cdot \Phi / H)-\Phi \cdot L \Psi] d D
\end{aligned}
$$

Since the integral of first term in the square brackets vanishes, the condition of minimum energy reduces to $\int_{D} \Phi \cdot(\Pi \cdot H-f) d D=0$. Now the minimal value $\Pi=\langle f\rangle /\langle H\rangle$ of PV can be easily found by means of the weighted mean value definition for an arbitrary function $F$

$$
\langle F\rangle=\int_{D} \Phi \cdot F d D / \int_{D} \Phi d D
$$

where $F_{\min } \leq\langle F\rangle \leq F_{\max }$ due to $\Phi \leq 0$. Consequently, equation (4) may be rewritten as

$$
L \Psi=\bar{\omega}^{(H)}+\bar{\omega}^{(f)}
$$

where

$$
\bar{\omega}^{(H)}=\langle f\rangle \cdot(H /\langle H\rangle-1) ; \bar{\omega}^{(f)}=\langle f\rangle-f
$$

represent the topographic and planetary relative background vorticity, respectively.

Thus, we come to a constructive definition of $\mathrm{BC}$ as the solution of the boundary problem (8), (5). Obviously, it is first necessary to find the distribution of the auxiliary function $\Phi$ as the solution of the boundary problem (6), and then to calculate the vorticity fields (9) using the definition (7).

According to the structure of the right-hand side of the linear problem (8), (5), the total BC in the field of integral streamfunction are the sum of three components: planetary $\mathrm{BC}$ $\Psi^{(f)}$ and topographic BC $\Psi^{(H)}$ with closed boundaries, and irrotational flow $\Psi^{(q)}$ caused by the water transport through the boundary $\partial D$. The parameter $\langle f\rangle$ defines the critical latitude, dividing areas of opposite vorticity in the planetary BC field: cyclonic (anticyclonic) in the southern (northern) parts of the sea, which gives a dipole character to the vorticity. The parameter $\langle H\rangle$ defines the critical isobath in a similar way, dividing the "shallow-" and "deep-water" parts of the sea, where the relative vorticity of the topographic BC has opposite signs: cyclonic when $H\rangle\langle H\rangle$ and anticyclonic when $H\langle\langle H\rangle$. So, the structure of the current depends significantly on the character
La substitución de (3) en (2) da lugar a la subsecuente ecuación para la función integral de corriente

$$
L \Psi=\Pi \cdot H-f
$$

Para el área casi cerrada $D$, la condición de frontera se puede escribir como

$$
\left.\Psi\right|_{\partial D}=\Psi^{(b)}(l, t)
$$

donde $l$ es una coordenada a lo largo de $\partial D$ y $\Psi^{(b)}$ es el transporte dado de agua, por ejemplo, a través de los estrechos. Para VP constante, la ley de conservación es idénticamente válida y la derivada $\Phi=\partial \Psi / \partial \Pi$, de acuerdo con (1) y (2), es la solución del problema de frontera

$$
L \Phi=H,\left.\Phi\right|_{\partial D}=0
$$

La energía cinética $E=(1 / 2) \cdot \int_{D}(1 / \mathrm{H}) \cdot(\nabla \Psi)^{2} d D$ es una función cuadrada del parámetro $\Pi$, donde $\nabla$ es un operador nabla bidimensional. La derivación por este parámetro da lugar a la expresión

$$
\begin{aligned}
\partial E / \partial \Pi & =\int_{D} H^{-1} \cdot \nabla \Psi \cdot \nabla \Phi d D \\
& =\int_{D}[\nabla(\nabla \Psi \cdot \Phi / H)-\Phi \cdot L \Psi] d D
\end{aligned}
$$

Debido a que la integral del primer término dentro de los paréntesis cuadrados es igual a cero, la condición de mínima energía se reduce a $\int_{D} \Phi \cdot(\Pi \cdot H-f) d D=0$. Ahora el valor mínimo $\Pi=\langle f\rangle /\langle H\rangle$ de VP puede ser fácilmente encontrado por medio de la definición del valor medio pesado para una función arbitraria $F$

$$
\langle F\rangle=\int_{D} \Phi \cdot F d D / \int_{D} \Phi d D
$$

donde $F_{\text {mín }} \leq\langle F\rangle \leq F_{\text {máx }}$ debido a $\Phi \leq 0$. Consecuentemente, la ecuación (4) puede ser reescrita como

$$
L \Psi=\bar{\omega}^{(H)}+\bar{\omega}^{(f)}
$$

donde

$$
\bar{\omega}^{(H)}=\langle f\rangle \cdot(H /\langle H\rangle-1) ; \bar{\omega}^{(f)}=\langle f\rangle-f
$$

representan la vorticidad relativa básica topográfica y planetaria, respectivamente.

Entonces, se llega a una definición constructiva de $\mathrm{CB}$ como la solución del problema de frontera (8), (5). Obviamente, primero es necesario encontrar la distribución 
of the bottom topography that could lead to a division into separate gyres. However, we can always confirm the cyclonic character of circulation in deep-water basins, and anticyclonic velocity shear on the shelf. The total $\mathrm{BC}$ field is determined by the values of relative contributions of all three components.

\section{Numerical results}

The calculations for the Gulf of California were carried out using spherical coordinates $(\lambda, \varphi)$ on a five-minute regular grid. The Coriolis parameter was, as usual, $f=2 \Omega \cdot \sin \varphi$, and the vorticity operator had the form $L \Psi=\left[\left(\Psi_{\varphi} \cos \varphi / H\right)_{\varphi}+\right.$ $\left.\left(\Psi_{\lambda} / H\right)_{\lambda} / \cos \varphi\right] /\left(R^{2} \cos \varphi\right)$, where $R$ and $\Omega$ are the average radius and the angular velocity of the Earth. The ETOPO5 bottom topography archive from the NOAA Oceanographic Data Center (www.nodc.noaa.gov) was used for grid construction and bottom relief approximation (fig. 1). To conserve the simply connected property of the area, a few islands were artificially submerged to a depth of $1 \mathrm{~m}$. Also, the narrow (in relation to grid step) channel between Tiburón Island and the mainland was neglected on the computational grid. The boundary problems (6) for auxiliary function $\Phi$ and (8), (5) for integral streamfunction $\Psi$ were approximated by a monotonic scheme of the second order of accuracy.

\section{Boundary conditions}

We considered a line across the entrance to the gulf as the single liquid boundary, neglecting river discharge. To use the

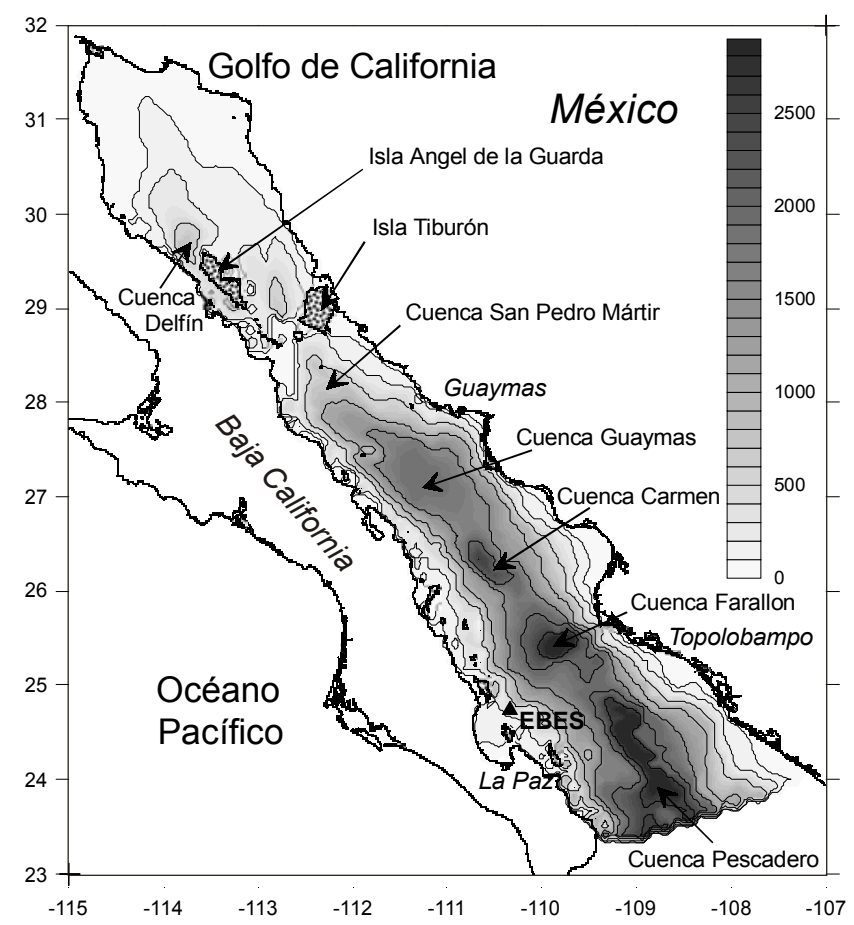

Figure 1. The Gulf of California bottom topography based on ETOPO5 archive of the NOAA Oceanographic Data Center.

Figura 1. Batimetría del Golfo de California basada en el archivo ETOPO5 del Centro de Datos Oceanográficos de la NOAA. de la función auxiliar $\Phi$ como la solución del problema de frontera (6) y después calcular los campos de vorticidad (9) usando la definición (7).

De acuerdo con la estructura del lado derecho del problema lineal (8), (5), las CB totales en el campo de la función integral de corriente son la suma de tres componentes: CB planetarias $\Psi^{(f)}$ y CB topográficas $\Psi^{(H)}$ con fronteras cerradas y un flujo irrotacional $\Psi^{(q)}$ causado por el transporte de agua a través de la frontera $\partial D$. El parámetro $\langle f\rangle$ define la latitud crítica, la cual divide las áreas con vorticidades opuestas en el campo de CB planetarias: ciclónica (anticiclónica) en la parte sur (norte) del mar, que da a la vorticidad un carácter de dipolo. El parámetro $\langle H\rangle$ define la isobata crítica de manera similar, dividiendo las partes de aguas "someras" y "profundas" del mar, donde la vorticidad relativa del campo de CB topográficas tiene signos opuestos: ciclónico cuando $H>\langle H\rangle$ y anticiclónico cuando $H<\langle H\rangle$. De esta manera, la estructura de la corriente depende significativamente del carácter de la topografía del fondo, que puede dar lugar a la división en giros separados. Sin embargo, siempre se puede confirmar el carácter ciclónico de la circulación en el área de las cuencas profundas y anticiclónico sobre la plataforma. El campo total de CB es determinado por los valores de las contribuciones relativas de todos los tres componentes.

\section{Resultados numéricos}

Los cálculos para el Golfo de California se llevaron a cabo utilizando coordenadas esféricas $(\lambda, \varphi)$ sobre una malla regular de cinco minutos. El parámetro de Coriolis fue, como es común, $f=2 \Omega \cdot \sin \varphi$, y el operador de vorticidad tiene la forma $L \Psi=\left[\left(\Psi_{\varphi} \cos \varphi / H\right)_{\varphi}+\left(\Psi_{\lambda} / H\right)_{\lambda} / \cos \varphi\right] /\left(R^{2} \cos \varphi\right)$, donde $R$ y $\Omega$ son el radio promedio y la velocidad angular de la Tierra. El archivo de la topografía del fondo ETOPO5 del Centro Oceanográfico de Datos de la NOAA (www.nodc.noaa.gov) fue usado para la construcción de la malla y para la aproximación del relieve del fondo (fig. 1). Para conservar la propiedad de área simplemente conexa, algunas islas fueron artificialmente sumergidas a una profundidad de $1 \mathrm{~m}$. Asimismo, el canal angosto (en relación con el paso de la malla) entre Isla Tiburón y el macizo continental fue despreciado en la malla computacional. Los problemas de frontera (6) para la función auxiliar $\Phi$ y (8), (5) para la función integral de corriente $\Psi$ fueron aproximados por un esquema monotónico de segundo orden de exactitud.

\section{Condiciones de frontera}

Como una frontera líquida se consideró solamente a la línea a través de la entrada al golfo, ignorando las descargas de ríos. Para usar la condición de frontera en la forma (5), se requiere conocer los valores de la función integral de corriente a través de la entrada del golfo, pero hasta ahora esta región no ha sido adecuadamente estudiada, al menos con respecto a la dirección $\mathrm{y}$ valor del transporte de agua. Una alternativa razonable (o un 
boundary condition in form (5) it is necessary to know the values of the integral streamfunction across the mouth, but until now, this area has not been adequately investigated, at least concerning the direction and value of water transport. A reasonable alternative (or supplementation) to (5) is the application of the so-called "free water passage" condition on the "liquid" part $\partial D_{l}$ of the total boundary, usually formulated by way of $\partial \Psi /\left.\partial \mathbf{n}\right|_{\partial D_{l}}=0$, where $\mathbf{n}$ is the normal vector to $\partial D_{l}$. The boundary problem (6) for the auxiliary function then becomes

$$
L \Phi=H ; \partial \Phi /\left.\partial \mathbf{n}\right|_{\partial D_{l}}=0,\left.\Phi\right|_{\partial D_{s}}=0
$$

where $\partial D_{s}$ is the "solid" part of the boundary, and therefore, the parameters $\langle f\rangle$ and $\langle H\rangle$ obtain other values. In calculations of $\mathrm{BC}$ we used both versions of the boundary condition, but mainly the second in this work.

\section{Planetary BC}

The boundary problem for this component is

$$
L \Psi^{(f)}=\bar{\omega}^{(f)}=\langle f\rangle-f ; \partial \Psi^{(f)} /\left.\partial \mathbf{n}\right|_{\partial D_{l}}=0,\left.\quad \Psi^{(f)}\right|_{\partial D_{s}}=0
$$

In the case of (10), the calculated parameter $\langle f\rangle$ gives the value $25^{\circ} 19^{\prime}$ for the critical latitude, above which the motion is anticyclonic and below which it is cyclonic. In the case of (6), i.e., the fully closed boundary (hereafter FCB), this value increases until $25^{\circ} 34.5^{\prime}$. The planetary $\mathrm{BC}$ in the field of the integral streamfunction $\Psi^{(f)}$ with amplitude $A^{(f)}=\Psi_{\max }^{(f)}-\Psi_{\min }^{(f)} \approx 22.07 \mathrm{~Sv}$ is shown in figure 2a. There are two gyres of anticyclonic rotation in the central and northern parts of the gulf, and a cyclonic gyre with amplitude of 14.25 Sv in the southern deep part. The central and northern gyres have amplitudes of less than $50 \%$ and about $20 \%$, respectively, of the amplitude of the southern ring. The total amplitude for the FCB case is $17.34 \mathrm{~Sv}$, but the intensities of the anticyclonic gyres remain nearly the same. The main difference is that the streamlines in the FCB case are closed in the mouth region.

\section{Topographic BC}

The topographic component of BC (fig. 2b) is a solution of the boundary problem

$$
\begin{aligned}
& L \Psi^{(H)}=\bar{\omega}^{(H)}=\langle f\rangle \cdot(H /\langle H\rangle-1) ; \\
& \partial \Psi^{(H)} /\left.\partial \mathbf{n}\right|_{\partial D_{l}}=0,\left.\quad \Psi^{(H)}\right|_{\partial D_{s}}=0
\end{aligned}
$$

The calculated critical depth is $1722.5 \mathrm{~m}(1659.7 \mathrm{~m}$ for the FCB case), and thus the area of relative topographic cyclonic vorticity according to (9) is located over the deep southern basin of the gulf, and consists of two nuclei over the Pescadero

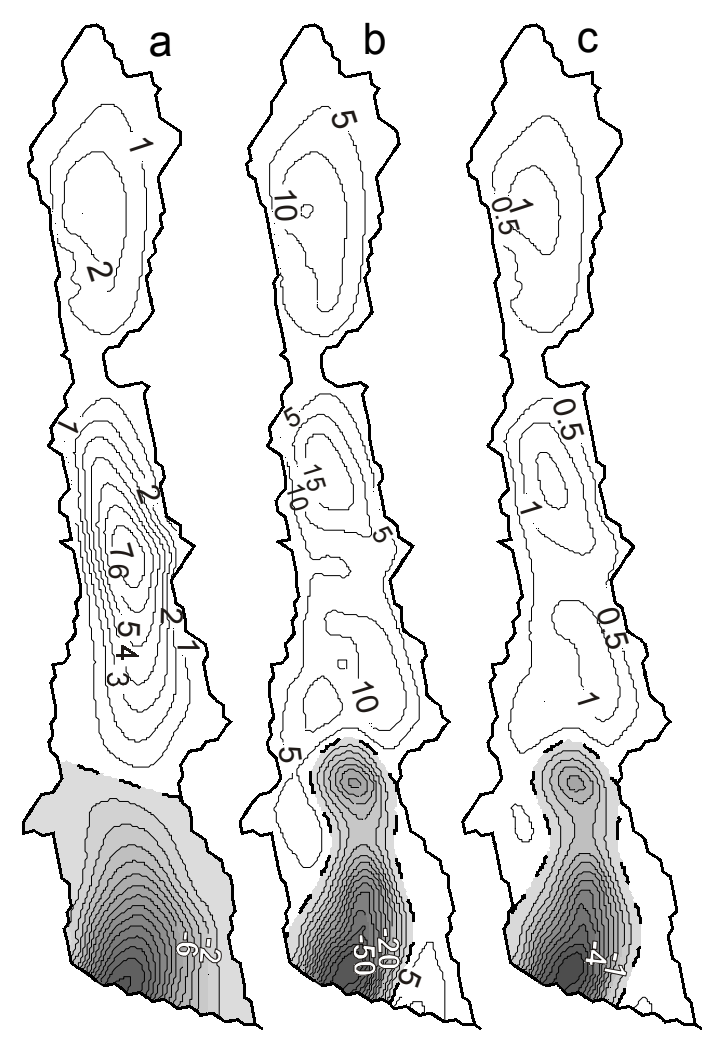

Figure 2. Streamfunctions in Sv of the integral circulation for (a) planetary, (b) topographic and (c) effective barotropic background currents in the Gulf of California. The efficiency parameter $\alpha$ for (c) is 0.07 . Darkened areas correspond to cyclonic circulation.

Figura 2. Funciones de corriente en Sv de la circulación integral para las componentes (a) planetaria, (b) topográfica y (c) corrientes básicas barotrópicas efectivas en el Golfo de California. El parámetro de eficiencia $\alpha$ para (c) es 0.07 . Las áreas oscuras corresponden a la circulación ciclónica.

suplemento) a (5) es la aplicación de la llamada condición de "paso libre del agua" en la parte "líquida" $\partial D_{l}$ de la frontera completa, formulada por la forma $\partial \Psi /\left.\partial \mathbf{n}\right|_{\partial D_{l}}=0$, donde $\mathbf{n}$ es un vector normal a $\partial D_{l}$. El problema de frontera (6) para la función auxiliar ahora se convierte en

$$
L \Phi=H ; \partial \Phi /\left.\partial \mathbf{n}\right|_{\partial D_{l}}=0,\left.\Phi\right|_{\partial D_{s}}=0
$$

donde $\partial D_{s}$ es la parte "sólida" de la frontera y, por tanto, los parámetros $\langle f\rangle$ y $\langle H\rangle$ obtienen otros valores. En los cálculos de $\mathrm{CB}$ se utilizaron ambas versiones de condición de frontera, pero principalmente la segunda en este trabajo.

\section{CB planetarias}

El problema de frontera para esta componente es

$$
L \Psi^{(f)}=\bar{\omega}^{(f)}=\langle f\rangle-f ; \partial \Psi^{(f)} /\left.\partial \mathbf{n}\right|_{\partial D_{l}}=0,\left.\quad \Psi^{(f)}\right|_{\partial D_{s}}=0
$$

En el caso de usar (10), el parámetro calculado $\langle f\rangle$ da el valor de $25^{\circ} 19^{\prime}$ para la latitud crítica, sobre la cual el movimiento es 
and Farallón basins. The region of opposite rotation in the central part of the gulf includes a few anticyclonic eddies according to features of the bottom topography. In the northern gulf, only one anticyclonic gyre is present. The southern cyclonic gyre is the most intense, with amplitude of $70 \mathrm{~Sv}$, while the total amplitude is $88.6 \mathrm{~Sv}$ (79.9 for the FCB case). Anticyclonic transport constitutes $17 \%$ and $21 \%$ of this value for the northern and central parts of the gulf, respectively. Topographic transport exceeds the planetary transport more than four times. In addition, these effects are in phase for the Gulf of California: the positions of the identically rotating gyres practically coincide for both components.

\section{Effective BC}

The total integral streamfunction for the barotropic $\mathrm{BC}$ is a sum of planetary and topographic streamfunctions, due to the linearity of equation (8). For the general case, there is a third component, a non-vortex flow $\Psi^{(q)}$, caused by the water transport through $\partial D$. The model gives the value $106.8 \mathrm{~Sv}$ (94.3 for the FCB case) for the total transport $A=\Psi_{\max }-\Psi_{\min }$, which exceeds the values observed in the upper layer by approximately one order of magnitude. A similar problem also appeared during the modeling of $\mathrm{BC}$ in the Japan and Okhotsk seas (Kozlov and Makarov, 1996a, b). This is a shortcoming of this barotropic model, which leaves out the known effect of damping to a surface of topographic fluctuations owing to vertical stratification. For an assessment of the surface circulation, we used a technique of Kozlov and Makarov (1996a), which consists essentially of some quantitative calibration, founded on estimation of real or supposed water transport across the liquid boundaries. We supposed that the effective $\mathrm{BC}$ in the upper layer could be obtained from the barotropic component with the use of the reduction or efficiency constant coefficient, i.e., $\Psi^{(e)}=\alpha \cdot\left(\Psi^{(H)}+\Psi^{(f)}\right)$, without taking $\Psi^{(q)}$ into consideration. To determine $\alpha$ for the Gulf of California, we used approximate evaluations of the water transport in the entrance area, which were obtained by Collins et al. (1997) on the basis of direct observations. The intensity of circulation at the mouth was about $5.8 \mathrm{~Sv}$ with the value of 0.07 obtained for the efficiency parameter $\alpha$. The maximum amplitude of the integral streamfunction $\Psi^{(e)}$ in the northern part of the gulf was near $1.2 \mathrm{~Sv}$, and in the central gulf near $1.6 \mathrm{~Sv}$.

Due to predominance of the topographic component, the effective BC for $\alpha=0.07$ presented in figure $2 \mathrm{c}$ is not considerably different from the scheme in figure $2 \mathrm{~b}$. The vector field of mean horizontal velocities may by easily constructed using the relations $u=-\Psi_{y}^{(e)} / H$ and $v=\Psi_{x}^{(e)} / H$. The result is shown in figure 3a. The maximal velocities (more then $0.5 \mathrm{~m} \mathrm{~s}^{-1}$ ) are observed over the shelf and in the vicinity of the archipelago in the northern part of the gulf. Lower speeds occur in the deep central region. In both areas the direction of movement is anticyclonic. The southern gulf has a more complicated velocity field, because of the strong cyclonic circulation in the middle and anticyclonic circulation near the coasts. anticiclónico y bajo la cual es ciclónico. En el caso (6), i.e., cuando la frontera está completamente cerrada (de aquí en adelante FCC), este valor se incrementa hasta $25^{\circ} 34.5^{\prime}$. Las CB planetarias en el campo de la función integral de corriente $\Psi^{(f)}$ con amplitud $A^{(f)}=\Psi_{\text {máx }}^{(f)}-\Psi_{\text {min }}^{(f)} \approx 22.07$ Sv se muestran en la figura 2a. Hay dos giros de rotación anticiclónica en las partes central y norte, y un giro ciclónico con amplitud de 14.25 Sv en la parte profunda del sur del golfo. Los giros central y norte tienen amplitudes menor del $50 \%$ y alrededor del $20 \%$, respectivamente, de la intensidad del giro del sur. Para el caso FCC, la amplitud total es de $17.34 \mathrm{~Sv}$, pero las intensidades de los giros anticiclónicos permanecen casi las mismas. La principal diferencia es que las líneas de corriente en el caso FCC están cerradas en la región de la boca.

\section{CB topográficas}

La componente topográfica de CB (fig. 2b) es la solución del problema de frontera

$$
\begin{aligned}
& L \Psi^{(H)}=\bar{\omega}^{(H)}=\langle f\rangle \cdot(H /\langle H\rangle-1) ; \\
& \partial \Psi^{(H)} /\left.\partial \mathbf{n}\right|_{\partial D_{l}}=0,\left.\quad \Psi^{(H)}\right|_{\partial D_{s}}=0
\end{aligned}
$$

La profundidad crítica calculada es igual a $1722.5 \mathrm{~m}(1659.7 \mathrm{~m}$ para el caso FCC) y, por tanto, el área de la vorticidad topográfica relativa ciclónica, de acuerdo con (9), se localiza sobre la cuenca profunda del sur del golfo y consiste de dos núcleos sobre las cuencas Pescadero y Farallón. La región de rotación opuesta en la parte central incluye algunos remolinos anticiclónicos de acuerdo con las características de la topografía del fondo. En el golfo norte sólo está presente un giro anticiclónico. El giro ciclónico en la parte sur es el más poderoso, con amplitud de $70 \mathrm{~Sv}$, mientras que la amplitud total es de $88.6 \mathrm{~Sv}$ (79.9 para el caso FCC ). El transporte anticiclónico en las partes norte y central del golfo constituye $17 \%$ y $21 \%$, respectivamente, de este valor. El transporte topográfico excede al transporte planetario más de cuatro veces. Además, estos efectos están en fase para el Golfo de California: las posiciones de los giros idénticamente rotados, prácticamente coinciden para ambas componentes.

\section{$C B$ efectivas}

La función integral total de corriente para las CB barotrópicas es la suma de las funciones de corriente planetaria y topográfica debido a la linealidad de la ecuación (8). En el caso general, hay un tercer componente, un flujo sin vorticidad $\Psi^{(q)}$, causado por el transporte de agua a través de la $\partial D$. Del modelo se obtiene un valor de 106.8 Sv (94.3 para el caso FCC) para el transporte total $A=\Psi_{\text {máx }}-\Psi_{\text {mín }}$, el cual excede los valores observados en la capa superior por aproximadamente un orden de magnitud. Un problema similar surgió también durante la 


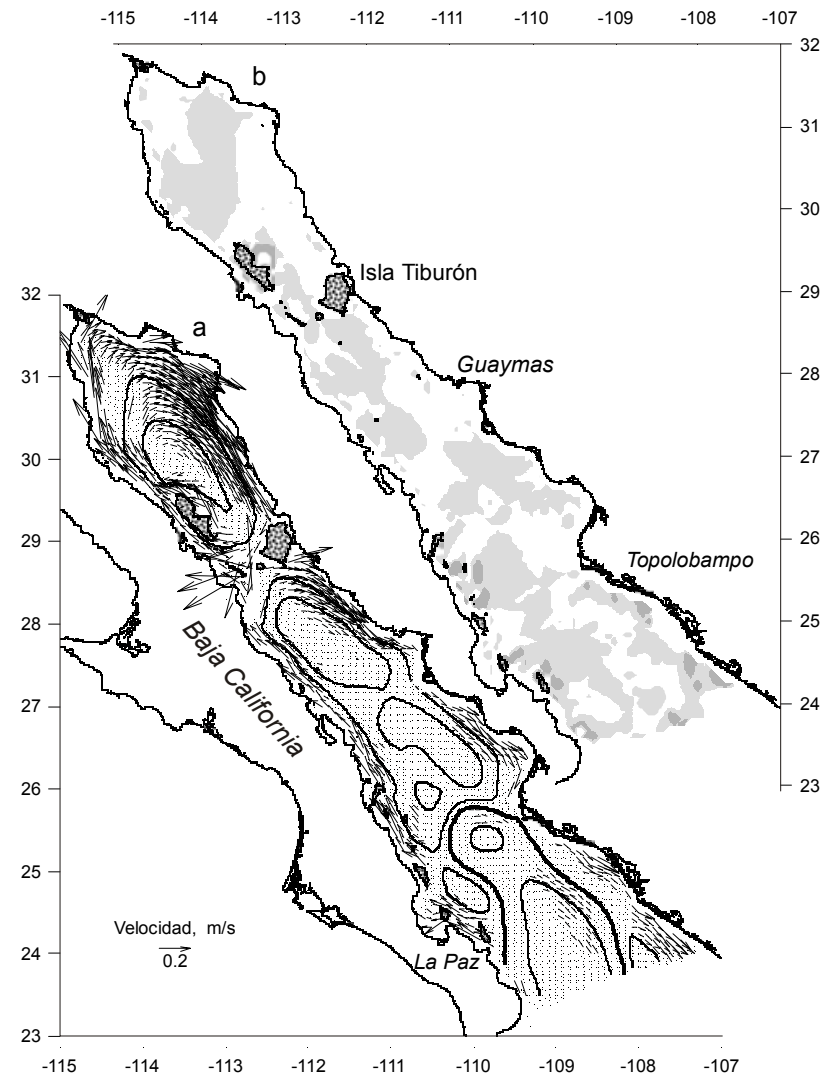

Figure 3. Barotropic effective background currents $(\alpha=0.07)$ in the Gulf of California: (a) vectors of the mean horizontal velocity and (b) upwelling zones. The darker areas indicate greater intensity of upwelling.

Figura 3. Corrientes básicas barotrópicas efectivas ( $\alpha=0.07)$ en el Golfo de California: (a) vectores de velocidad horizontal media y (b) zonas de surgencias. Las áreas oscurecidas indican mayor intensidad de surgencias.

A qualitative analysis of the vertical velocities is possible using the expression

$$
d=u_{x}+v_{y} \equiv\left(1 / H^{2}\right) \cdot J\left(H, \Psi^{(e)}\right)
$$

for the horizontal divergence, where $J$ is the Jacobian. It is evident that (11) gives only direction of vertical movement, but not magnitudes. The calculated upwelling zones are shown in figure $3 \mathrm{~b}$, where darkened areas indicate greater intensity. The spatial distribution of the horizontal divergence has a spotted appearance, correlated with a complicated bottom relief.

\section{Discussion and conclusions}

We now compare the calculated effective $\mathrm{BC}$ pattern (fig. 3a) in the Gulf of California with prevalent concepts about the character of circulation in this region. An anticyclonic movement of considerable speeds occupies the northern part of the gulf. The presence of this permanent gyre, which in a longer winter has anticyclonic rotation, is confirmed by the analysis of hydrological observations and direct measurements (e.g., Lavín et al., 1997b). Most numerical models reproduce modelación de CB para los mares de Japón y Okhotsk (Kozlov y Makarov, 1996a, b). Esto es un defecto del modelo barotrópico, el cual omite el conocido efecto de atenuación hacia la superficie de fluctuaciones topográficas debido a la estratificación vertical. Para la evaluación de la circulación superficial se usó una técnica de Kozlov y Makarov (1996a), la cual esencialmente consiste de alguna calibración cuantitativa, basada en la estimación real o supuesta del transporte de agua a través de las fronteras líquidas. Se supuso que las CB efectivas en la capa superficial pueden ser obtenidas de la componente barotrópica con el uso del coeficiente constante de la reducción o de eficiencia, i.e., $\Psi^{(e)}=\alpha \cdot\left(\Psi^{(H)}+\Psi^{(f)}\right)$, sin tomar $\Psi^{(q)}$ en consideración. Para determinar $\alpha$ para el Golfo de California se usaron evaluaciones aproximadas del transporte de agua en la región de la entrada, las cuales fueron obtenidas por Collins et al. (1997) con base en observaciones directas. La intensidad de la circulación en la boca fue de alrededor de $5.8 \mathrm{~Sv}$ con el valor 0.07 obtenido para el parámetro de eficiencia $\alpha$. La máxima amplitud de la función integral de corriente $\Psi^{(e)}$ estuvo cerca de $1.2 \mathrm{~Sv}$ en la parte norte del golfo y cerca de $1.6 \mathrm{~Sv}$ en la parte central.

Debido a la predominancia de la componente topográfica, las $\mathrm{CB}$ efectivas con $\alpha=0.07$ presentadas en la figura $2 \mathrm{c}$ no son considerablemente diferentes del esquema en la figura $2 b$. El campo vectorial de velocidades horizontales medias puede ser fácilmente construido usando las relaciones $u=-\Psi_{y}^{(e)} / H \mathrm{y}$ $v=\Psi_{x}^{(e)} / H$. El resultado se muestra en la figura 3a. Las velocidades máximas (más de $0.5 \mathrm{~m} \mathrm{~s}^{-1}$ ) se observan sobre la plataforma y en la vecindad del archipiélago en la parte norte del golfo. Velocidades más débiles se presentan en la parte profunda central. En ambas áreas la dirección del movimiento es anticiclónico. La parte sur del golfo tiene un campo de velocidades más complicado debido a la presencia de la fuerte circulación ciclónica en la parte media y circulación anticiclónica cerca de las costas.

Es posible hacer el análisis cualitativo de las velocidades verticales usando la expresión

$$
d=u_{x}+v_{y} \equiv\left(1 / H^{2}\right) \cdot J\left(H, \Psi^{(e)}\right)
$$

para la divergencia horizontal, donde $J$ es el jacobiano. Es evidente que (11) proporciona solamente la dirección del movimiento vertical, pero no las magnitudes. Las zonas de surgencias calculadas se muestran en la figura $3 b$, donde las áreas oscuras indican una mayor intensidad. La distribución espacial de la divergencia horizontal tiene la apariencia de parches, correlacionada con un complicado relieve del fondo.

\section{Discusión y conclusiones}

Ahora se compara el patrón de CB efectivas calculadas (fig. 3a) en el Golfo de California con los conceptos prevalecientes con respecto al carácter de la circulación en esta región. Un movimiento anticiclónico con velocidades considerables 
this gyre. In a shorter summer, however, the direction of currents (as well as wind) reverses due to seasonal variability in the basic geophysical parameters of this generally shallow region (e.g., Carrillo et al., 2002).

In our scheme, a well-organized southward flow with speeds of about $0.2 \mathrm{~m} \mathrm{~s}^{-1}$ occurs in the main gulf, along practically all the mainland coast. The existence of such a stream in the winter season is confirmed by both observations and numerical results (Beier, 1997; Argote et al., 1998; Marinone, 1998; Velasco-Fuentes and Marinone, 1999). An opposite northward flow along the coast of the peninsula is also present, but this is not so well organized either in summer or in winter, as figure $3 \mathrm{a}$ demonstrates. Over the deep part of the central gulf above $26^{\circ} \mathrm{N}$, the movement is anticyclonic with low speeds. There is a point of view (Álvarez-Sánchez et al., 1978; Bray, 1988a; Beier, 1997) that the surface circulation patterns there and in the entrance zone also have strong seasonal features. However, Marinone and Ripa (1988) did not find a significant seasonal signal either for surface circulation or, notably, for deep-water circulation for the Guaymas region, for example. Neither did they find a seasonal signal for the relative vorticity field (Ripa and Marinone, 1989). Nevertheless, changes in wind and surface heat flux directions in summer lead to reconstruction of the thermohaline structure; at least wind and baroclinicity in the gulf are in phase (Beier, 1997). These effects, and probably a transformation of the Kelvin wave that penetrates from the Pacific (e.g., Ripa, 1997), evidently dominate in the upper layer and have an effect against the planetary-topographic mechanisms in summer. Therefore, at least on the surface, the directions of currents can reverse, including the alongshore flows, which may have a baroclinic origin.

The circulation in the southern part of the gulf, especially in the mouth region, is very intricate. As shown in figure $3 a$, a powerful cyclonic gyre exists over the entire deep-water area. Its intensity consists of almost $80 \%$ of the total intensity for the entire gulf circulation. The gyre has two cores: one located above the Pescadero basin, in the mouth of the gulf, and the other one above the Farallón basin. At the same time, circulation in the vicinity of La Paz Bay and near the Sinaloa coast, where the continental slope is rather flat, remains anticyclonic. The heavy line in figure $3 \mathrm{a}$ indicates the boundary between cyclonic and anticyclonic regions; essentially it is a dynamic front. According to the scheme proposed here, the main inflow of ocean water occurs through the central part of the mouth, closer to the mainland, and the outflow from the gulf is carried along both coasts. Velasco-Fuentes and Marinone (1999) obtained a similar result for winter with a nonlinear, vertically integrated, barotropic model on the $f$-plane. The analysis of the geostrophic flows, calculated with a dynamic method on the basis of observations from November to December 1969 (Roden, 1972) and February 1992 (Fernández-Barajas et al., 1994), also lead to similar patterns. In August 1992, the inflow was deepened and occurred below 100 m (Fernández-Barajas et al., 1994). The detailed examinations of this region, which ocupa la parte norte del golfo. La presencia de este giro permanente, el cual en un invierno tiene una rotación anticiclónica, se confirma por el análisis de observaciones hidrológicas y mediciones directas (e.g., Lavín et al., 1997b). La mayoría de los modelos numéricos reproducen este giro. Sin embargo, en un verano corto, la dirección de las corrientes (así como del viento) se revierte debido a la variabilidad estacional de los parámetros geofísicos básicos en esta región, generalmente somera (e.g., Carrillo et al., 2002).

En nuestro esquema, en la parte principal del golfo ocurre un flujo bien organizado hacia el sur a lo largo de prácticamente toda la costa continental, con velocidades de alrededor de $0.2 \mathrm{~m} \mathrm{~s}^{-1}$. La existencia de tal corriente en la estación de invierno se confirma tanto por observaciones como por resultados numéricos (Beier, 1997; Argote et al., 1998; Marinone, 1998; Velasco-Fuentes y Marinone, 1999). Un flujo opuesto, hacia el norte, a lo largo de la costa de la península también está presente, pero no está tan bien organizado ni en verano ni en invierno, como se muestra en la figura $3 \mathrm{a}$. Sobre la parte profunda del golfo central, al norte de los $26^{\circ} \mathrm{N}$, el movimiento es anticiclónico con velocidades débiles. Existe un punto de vista (Álvarez-Sánchez et al., 1978; Bray, 1988a; Beier, 1997) de que los patrones de circulación superficial, ahí y en la zona de la entrada, también tienen fuertes características estacionales. Sin embargo, Marinone y Ripa (1988) no encontraron una señal estacional significativa para la circulación superficial y, notablemente, para la circulación de agua profunda en la región de Guaymas, por ejemplo. Tampoco encontraron una señal estacional para el campo de vorticidad relativa (Ripa y Marinone, 1989). No obstante, cambios en las direcciones del viento y del flujo de calor superficial en verano dan lugar a la reconstrucción de la estructura termohalina; al menos el viento y la baroclinicidad en el golfo están en fase (Beier, 1997). Estos efectos, y probablemente la transformación de una onda de Kelvin que penetra desde el Pacífico, evidentemente dominan en la capa superior y durante el verano tienen un efecto contra los mecanismos planetarios-topográficos. Por lo tanto, al menos en la superficie, la dirección de las corrientes puede revertirse, incluyendo los flujos a lo largo de las costas, los cuales pueden tener un origen baroclínico.

La circulación en la parte sur del golfo, especialmente en la región de la boca, es muy intrincada. Como se muestra en la figura $3 \mathrm{a}$, un poderoso remolino ciclónico existe sobre toda el área de agua profunda. Su intensidad consiste de casi el $80 \%$ de la intensidad total de la circulación entera del golfo. El giro tiene dos núcleos, uno localizado sobre la cuenca Pescadero, en la boca del golfo, y el otro sobre la cuenca Farallón. Al mismo tiempo, la circulación en la vecindad de la Bahía de La Paz y cerca de la costa de Sinaloa, donde la pendiente continental no es tan brusca, permanece anticiclónica. La línea sólida de la figura 3a indica la frontera entre las regiones ciclónica y anticiclónica; esencialmente, esta línea es un frente dinámico. De acuerdo con el esquema propuesto aquí, el flujo principal de entrada de aguas oceánicas ocurre a través de la parte central de la boca, más cerca de la costa continental, y el flujo 
were carried out in April, May and December 1992 (Collins et al., 1997), and the observations from eight oceanographic cruises between 1992 and 1998 (Castro et al., 2000), indicated that the exchange of water between the gulf and the Pacific Ocean, in the southern part of Pescadero Basin, occurred via cyclonic circulation throughout most of the year. No evidence of the outflow from the gulf along the Sinaloa coast exists in these data, however. The cyclonic vortex in the region of the Farallón Basin, first detected through direct measurement by Emilsson and Alatorre (1997) in August 1978, was also present in a field of geostrophic flows for February and August 1992 (Fernández-Barajas et al., 1994). Amador-Buenrostro et al. (2003) reported that the cyclonic structure was almost permanently present in this region on the satellite images. They gave results of direct measurements for the end of November 1997 that demonstrate the existence of this structure. The northward flow near La Paz Bay was also detected in these observations. Such a situation may lead to anticyclonic eddy generation in the vicinity of the EBES seamount. González-Armas et al. (2002) came to similar conclusions based on analyses of copepod and macrozooplankton distributions around the EBES seamount that indicated an upwelling in addition to the probable presence of the eddy. Upwelling also has a place here in our horizontal divergence distribution (fig. 3b). This scheme demonstrates the presence of rather intensive upwelling, mainly on both coasts of the gulf, in the archipelago and in the upper half of the northern gulf. The existence of upwelling in these regions is confirmed by both observations and analysis of satellite images (Badan-Dangon et al., 1985; Álvarez-Borrego and Lara-Lara, 1991; Santamaría-del-Ángel and ÁlvarezBorrego, 1994; Santamaría-del-Ángel et al., 1999). It should be noted that coastal upwelling in the gulf is usually connected to the effects of wind stress: the winter upwelling occurs predominately at the mainland, and the summer upwelling, usually weak, occurs near the coast of the peninsula.

Thus, the calculated barotropic BC realistically describe the main features of actual circulation in the southern part of the Gulf of California, including the region of the entrance. The good agreement with the observations suggests that largely planetary-topographical effects support the main circulation in this region. It should be noted that the topography plays a noticeable role in forming the baroclinic structure. The seasonal variability in the southern gulf is apparently not so strongly expressed, except for a surface layer. The background circulation in the central and northern parts of the gulf, where there are drastic seasonal climatological changes, coincides with observations in the upper layer for only the longer winter season. It is clear that the calculated $\mathrm{BC}$ are affected chiefly by the contribution of the lower layer. Thus, the predominantly surface seasonal variability is apparently in phase with barotropic planetary-topographic mechanisms during winter and in antiphase during summer.

The authors do not want to overestimate the importance of the barotropic model used here, which can exaggerate the topographical circulation component, while failing to consider de salida del golfo tiene lugar a lo largo de ambas costas. Velasco-Fuentes y Marinone (1999) han obtenido un resultado similar para invierno con un modelo barotrópico, no lineal, verticalmente integrado, sobre el plano $f$. El análisis de los flujos geostróficos, calculados con el método dinámico a partir de las observaciones de noviembre a diciembre de 1969 (Roden, 1972) y febrero de 1992 (Fernández-Barajas et al., 1994), también dio lugar a patrones similares. En agosto de 1992, el flujo de entrada fue más profundo y ocurrió por debajo de los $100 \mathrm{~m}$ (Fernández-Barajas et al., 1994). Los estudios detallados de esta región, los cuales fueron llevados a cabo en abril, mayo y diciembre de 1992 (Collins et al., 1997), así como las observaciones de ocho cruceros oceanográficos entre 1992 y 1998 (Castro et al., 2000), indicaron que el intercambio de agua entre el golfo y el Océano Pacífico en la parte sur de la cuenca Pescadero ocurrió vía la circulación ciclónica durante casi todo el año. Sin embargo, estos datos no mostraron la existencia del flujo hacia afuera del golfo a lo largo de la costa de Sinaloa. El remolino ciclónico en la región de la cuenca Farallón, que fue detectado por primera vez en agosto de 1978 por Emilsson y Alatorre (1997) con base en mediciones directas, también estaba presente en el campo de flujos geostróficos para febrero y agosto de 1992 (Fernández-Barajas et al., 1994). AmadorBuenrostro et al. (2003) reportaron que la estructura ciclónica casi permanente estaba presente en esta región en imágenes de satélite. Ellos presentaron resultados de mediciones directas para fines de noviembre de 1997 que muestran la existencia de esta estructura. El flujo hacia el norte cerca de la Bahía de La Paz también se detectó en estas observaciones. Tal situación puede dar lugar a la generación de un remolino anticiclónico en la vecindad de la montaña submarina EBES. González-Armas et al. (2002) llegaron a conclusiones similares basándose en análisis de distribuciones de copépodos y de macrozooplancton alrededor de la montaña submarina EBES que indicaban la existencia de una surgencia, además de la probable presencia del remolino. La surgencia también tiene lugar en nuestra distribución de la divergencia horizontal (fig. 3b). Este esquema demuestra la presencia de las surgencias bastante intensas, principalmente en ambas costas del golfo, en la región del archipiélago y en la mitad superior del golfo norte. La existencia de las surgencias en estas regiones está confirmada por observaciones y por análisis de imágenes de satélite (BadanDangon et al., 1985; Álvarez-Borrego y Lara-Lara, 1991; Santamaría-del-Ángel y Álvarez-Borrego, 1994; Santamaríadel-Ángel et al., 1999). Debe hacerse notar que la surgencia costera en el golfo usualmente está conectada a efectos de esfuerzo del viento: las surgencias de invierno se presentan predominantemente en la costa continental y las surgencias de verano, frecuentemente débiles, se presentan cerca de la costa de la península.

Por tanto, las CB barotrópicas calculadas describen, de una manera realista, las características principales de la circulación actual en la parte sur del Golfo de California, incluyendo la región de la entrada. La buena concordancia con las observaciones sugiere que los efectos planetarios- 
other significant factors. Within the framework of the definition of $\mathrm{BC}$ utilized here, the construction of more complicated quasi-geostrophic models for the two-layer and continuously stratified ocean is possible (Kozlov, 1995). This approach dampens topographic fluctuations, and in the immediate future, we propose using the model of baroclinic ocean for this area. The model can also be applied to the creation of a stationary mean flow field as background for the examination of non-stationary effects, including chaotic advection (Kozlov and Koshel', 1999). In any case, even this elementary barotropic model of $\mathrm{BC}$ has allowed us to construct a realistic background circulation for the Gulf of California as reference.

\section{Acknowledgements}

This research was supported by funding from the Mexican National Polytechnical Institute (No. 20010321). We thank the anonymous reviewers for their suggestions and comments, which improved the text, and William P. Black for editing the English-language text.

\section{References}

Álvarez-Borrego, S. (1983). Gulf of California. In: B.H. Ketchum (ed.), Estuaries and Enclosed Seas. Elsevier, Amsterdam, pp. 427-448.

Álvarez-Borrego, S. and Lara-Lara, J.R. (1991). The physical environment and primary productivity of the Gulf of California. In: J.P. Dauphin and B.R. Simoneit (eds.), The Gulf and Peninsular Province of the Californias. Am. Assoc. Pet. Geol., Mem., 47: 555-567.

Álvarez-Sánchez, L.G., Wyatt, B. y Stevenson, M.R. (1978). Corrientes en la región de la boca del Golfo de California en la primavera de 1970. Ciencias Marinas, 5(1): 105-118.

Amador-Buenrostro, A., Trasviña-Castro, A., Muhlia-Melo, A. and Argote-Espinoza, M.L. (2003). Structure of the flow on the EBES seamount and the Farallón basin in the Gulf of California, November 1997. Geofísica Internacional (in press).

Argote, M.L., Lavín, M.F. and Amador, A. (1998). Barotropic eulerian residual circulation in the Gulf of California due to the M2 tide and wind stress. Atmósfera, 11: 173-197.

Badan-Dangon, A., Koblinsky, C.J. and Baumgartner, T. (1985). Spring and summer in the Gulf of California: Observations of surface thermal patterns. Oceanol. Acta, 8(1): 13-22.

Badan-Dangon, A., Dorman, C.E., Merrifield, M.A. and Winant, C.D. (1991). The lower atmosphere over the Gulf of California. J. Geophys. Res., 96(C9): 16877-16896.

Baumgartner, T.R. and Christensen, Jr. N. (1985). Coupling of the Gulf of California to large-scale interannual climatic variability. J. Mar. Res., 43: 825-848.

Beier, E. (1997). A numerical investigation of the annual variability in the Gulf of California. J. Phys. Oceanogr., 27: 615-632.

Bray, N.A. (1988a). Thermohaline circulation in the Gulf of California. J. Geophys. Res., 93(C5): 4993-5020.

Bray, N.A. (1988b). Water mass formation in the Gulf of California. J. Geophys. Res., 93(C8): 9223-9240.

Bray, N.A. and Robles, J.M. (1991). Physical Oceanography of the Gulf of California. In: J.P. Dauphin and B.R. Simoneit (eds.), The topográficos predominantemente producen la circulación principal en esta región. Debe hacerse notar que la topografía juega un papel notable en la formación de la estructura baroclínica. La variabilidad estacional en la parte sur del golfo aparentemente no está tan fuertemente expresada, excepto en la capa superficial. La circulación básica en las partes central y norte del golfo, donde los cambios climatológicos estacionales son muy drásticos, coincide con las observaciones de la capa superior solamente para una estación invernal. Es claro que las $\mathrm{CB}$ calculadas son afectadas principalmente por la contribución de la capa inferior. Entonces, la variabilidad estacional que es predominantemente superficial, posiblemente está en fase con los mecanismos barotrópicos planetarios-topográficos durante invierno y en antifase durante verano.

Los autores no quieren sobrestimar la importancia del modelo barotrópico utilizado aquí, el cual puede exagerar la componente topográfica de la circulación, mientras que al mismo tiempo falla al no considerar otros factores significativos. Dentro de la definición de CB utilizada aquí es posible construir los modelos cuasigeostróficos más complicados: de dos capas y de un océano continuamente estratificado (Kozlov, 1994). Este enfoque puede atenuar las fluctuaciones topográficas y en el futuro inmediato proponemos aplicar, para esta región, el modelo del océano baroclínico. El modelo también puede ser aplicado para la creación de un campo de flujo medio estacionario como la base para el estudio de efectos no estacionarios, incluyendo advección caótica (Kozlov y Koshel', 1999). En cualquier caso, aun este sencillo modelo barotrópico de $\mathrm{CB}$ nos ha permitido construir, como una referencia, la circulación básica del Golfo de California suficientemente apegada a la realidad.

\section{Agradecimientos}

Esta investigación recibió apoyo financiero del Instituto Politécnico Nacional (No. 200110321). Se agradece a los revisores anónimos sus sugerencias y comentarios, las cuales mejoraron el texto del artículo, y a William P. Black la edición del texto escrito en inglés.

Traducido al español por los autores.

Gulf and Peninsular Province of the Californias. Am. Assoc. Pet. Geol., Mem., 47: 511-553.

Cano-Pérez, F.A. (1991). Golfo de California: Oceanografía física. En: G. Lanza-Espino (ed.), Oceanografía de Mares Mexicanos. AGT Editor, México, D.F., pp. 453-514.

Carbajal, N. (1993). Modeling of the circulation in the Gulf of California. Ph.D. thesis, Institute fur Meerskunde, Hamburg, $186 \mathrm{pp}$.

Carrillo, L., Lavín, M.F. and Palacios-Hernández, E. (2002). Seasonal evolution of the geostrophic circulation in the northern Gulf of California. Estuar. Coast. Shelf Sci., 54(2): 157-173.

Castro, R., Mascarenhas, A.S., Durazo R. y Collins, C.A. (2000). Variación estacional de la temperatura y salinidad en la entrada del Golfo de California, México. Cien. Mar., 26(4): 561-583. 
Collins, C.A., Garfield, N., Mascarenhas Jr. A.S. and Sperman, M.G. (1997). Ocean current across the entrance to the Gulf of California. J. Geophys. Res., 102(C9): 20927-20936.

Dressler, R. (1981). Investigación sobre mareas y efectos de viento en el Golfo de California, mediante un modelo H-N. Sammlung von Publikationen Dressler. Nr. 2. Unpublished manuscript, 26 pp.

Emilsson, I. y Alatorre, M.A. (1997). Evidencias de un remolino ciclónico de mesoescala en la parte sur del Golfo de California. En: M.F. Lavín (ed.), Contribuciones a la Oceanografía Física en México. Monografía No. 3, Unión Geofísica Mexicana, México, pp. 173-182.

Fernández-Barajas, M.E., Monreal-Gómez, M.A. y Molina-Cruz, A. (1994). Estructura termohalina y flujo geostrófico, en el Golfo de California, durante 1992. Cien. Mar., 20(2): 267-286.

González-Armas, R., Palomares-García, R. and Silvia-Dávila, R. (2002). Copepod and macrozooplankton distribution associated to El Bajo Espíritu Santo seamount. In: M.E. Hendrickx (ed.), Contribution to the Study of East Pacific Crustaceans. Instituto de Ciencias del Mar y Limnología, UNAM, México, pp. 183-193.

Kozlov, V.F. (1995). Background currents in geophysical hydrodynamics. Izv. Atmos. Ocean. Phys., 31(2): 229-234.

Kozlov, V.F. and Makarov, V.G. (1996a). Background currents in the Sea of Japan (a barotropic model). Oceanology, 35(3): 601-604.

Kozlov, V.F. and Makarov, V.G. (1996b). Background currents in the Sea of Okhotsk. Russ. Meteorol. Hydrol., 9: 39-44.

Kozlov, V.F. and Koshel', K.V. (1999). Barotropic model of chaotic advection in background flows. Izv. Atmos. Ocean. Phys., 35(1): 123-130.

Lavín, M.F., Beier, E. y Badan, A. (1997a). Estructura hidrográfica y circulación del Golfo de California: Escalas estacional e interanual. En: M.F. Lavín (ed.), Contribuciones a la Oceanografía Física en México. Monografía No. 3, Unión Geofísica Mexicana, México, pp.141-171.

Lavín, M.F., Durazo, R., Palacios, E., Argote, M.L. and Carillo, L. (1997b). Lagrangian observations of the circulation in the northern Gulf of California. J. Phys. Oceanogr., 27(10): 2298-2305.

Marinone, S.G. (1997). Tidal residual currents in the Gulf of California: Is the M2 tidal constituent sufficient to induce them? J. Geophys. Res., 102(C4): 8611-8623.

Marinone, S.G. (1998). Effect of the topographic stress on the tideand wind-induced residual currents in the Gulf of California. J. Geophys. Res., 103(C9): 18437-18446.

Marinone, S.G. and Ripa, P. (1988). Geostrophic flow in the Guaymas Basin, central Gulf of California. Cont. Shelf Res., 8(2): 159-166.
Marinone, S.G. and Lavín, M.F. (1997). Mareas y corrientes residuales en el Golfo de California. En: M.F. Lavín (ed.), Contribuciones a la Oceanografía Física en México. Monografía No. 3, Unión Geofísica Mexicana, México, pp.111-131.

Martínez, A. (2002). Modeling studies of mesoscale circulation in the Gulf of California. Ph.D. thesis, Oregon State University.

Paden, C.A., Abbott, M.R. and Winant, C.D. (1991). Tidal and atmospheric forcing of the upper ocean in the Gulf of California. 1. Sea surface temperature variability. J. Geophys. Res., 96(C10): 18337-18359.

Pedlosky, J. (1979). Geophysical Fluid Dynamics. Springer-Verlag, New York, 624 pp.

Rhines, P.B. and Young, W.R. (1982). Homogenization of potential vorticity in planetary gyres. J. Fluid Mech., 122: 347-357.

Ripa, P. (1997). Towards a physical explanation of the seasonal dynamics and thermodynamics of the Gulf of California. J. Phys. Oceanogr., 27: 597-614.

Ripa, P. and Marinone, S.G. (1989). Seasonal variability of temperature, salinity, velocity, vorticity and sea level in the central Gulf of California, as inferred from historical data. Q. J. R. Meteorol. Soc., 115: 887-913.

Robles, J.M. and Marinone, S.G. (1987). Seasonal and interannual thermohaline variability in the Guaymas Basin of the Gulf of California. Cont. Shelf Res., 7(7): 715-733.

Roden, G.I. (1958). Oceanographic and meteorological aspects of the Gulf of California. Pacific Sci., 12(1): 21-45.

Roden, G.I. (1964). Oceanographic aspect of the Gulf of California. In: Tj.H. van Andel and G.G. Shor Jr. (eds.), Marine Geology of the Gulf of California: A Simposium. Am. Assoc. Pet. Geol., Mem., 3: 30-58.

Roden, G.I. (1972). Thermohaline structure and baroclinic flow across the Gulf of California entrance and in the Revillagigedo Islands region. J. Phys. Oceanogr., 2: 177-183.

Santamaría-del-Ángel, E. and Álvarez-Borrego, S. (1994). Gulf of California biogeographic regions based on coastal zone color scanner imagery. J. Geophys. Res., 99(C4): 7411-7423.

Santamaría-del-Ángel, E., Álvarez-Borrego, S., Millán-Núñez, R. y Muller-Karger, F.E. (1999). Sobre el efecto débil de las surgencias de verano en la biomasa fitoplanctónica del Golfo de California. Rev. Soc. Mex. Hist. Nat., 49: 207-212.

Velasco-Fuentes, O.U. and Marinone, S.G. (1999). A numerical study of the Lagrangian circulation in the Gulf of California. J. Mar. Syst., 22: 1-12.

Von Schwind, J.J. (1980). Geophysical Fluid Dynamics for Oceanographers. Prentice-Hall, Englewood Cliffs, New York, $307 \mathrm{pp}$. 